\title{
Fibronectin increases RhoA activity through inhibition of PKA in the human gastric cancer cell line SGC-7901
}

\author{
YONGJIN LI, YONGCHANG CHEN, YAN TAO, YING WANG, YUEFANG CHEN and WENRONG XU
}

School of Medical Science and Laboratory Medicine, Jiangsu University, Jiangsu 212013, P.R. China

Received July 15, 2010; Accepted October 29, 2010

DOI: $10.3892 / \mathrm{mmr} .2010 .396$

\begin{abstract}
Fibronectin/integrin-mediated signaling plays a key role in the regulation of adhesion, migration and metastasis of tumors. Numerous studies have addressed the significance of the association between integrin and RhoA, but the exact mechanism is unclear. Results from laboratories, including ours, have demonstrated that PKA inhibits the activity and function of RhoA. This study was designed to investigate the relationships among the fibronectin/integrin-, cAMP/PKAand RhoA-mediated intracellular signal transduction pathways. Rho activity was detected by pull-down assay. cAMP concentration was measured by radioimmunoassay. The distribution of the PKA catalytic subunit and the phosphorylation of vasodilator-stimulated phosphoprotein (VASP) were detected by fluorescence microscopy and Western blotting, respectively, to examine the activation of PKA. cAMP-mediated gene expression activity was analyzed using a luciferase reporter gene assay. The results revealed that, in SGC-7901 cells, soluble fibronectin increased RhoA activity and blocked the inhibition of RhoA activity by cAMP/PKA. The cAMP level, which was increased by forskolin and pertussis toxin, was decreased by fibronectin. The nuclear location of the PKA catalytic unit, the phosphorylation of VASP and cAMP response element (CRE)directed reporter gene expression induced by forskolin were blocked by fibronectin. However, fibronectin did not block VASP phosphorylation or CRE-directed reporter gene expression induced by cAMP. These data suggest that fibronectin/ integrin induces RhoA activation through the inhibition of cAMP/PKA signal transduction. The possible point of action of fibronectin/integrin is adenylate cyclase.
\end{abstract}

\section{Introduction}

Integrin is an important receptor of cellular adhesion molecules and mediates cell-to-cell and cell-to-extracellular matrix adhesion (1). It has been demonstrated that cell adhesion is correlated with the growth, invasion and metastasis of tumors (2).

Correspondence to: Dr Yuefang Chen, Department of Physiology, Jiangsu University, Zhenjiang, Jiangsu 212013, P.R. China E-mail: ycchen54@ujs.edu.cn

Key words: fibronectin, integrin, RhoA, PKA, cAMP
RhoA is a key member of the Rho family of small GTP-binding proteins and mediates signaling relating to cytoskeleton arrangement, migration, proliferation and gene expression (3-5). Previous studies have found that invasive growth and metastasis were inhibited in a variety of cancer cells overexpressing RhoA when RhoA activity was inhibited (6-8). Numerous studies have addressed the significance of the association between integrin and RhoA (9), but the exact mechanism through which integrin increases the activity of RhoA is unclear. PKA is a protein kinase related to the cAMP signaling pathway. Studies have suggested that PKA inhibits the activity and function of RhoA $(7,10)$. The possible interactions among integrin, RhoA and PKA are unknown. This study examined the relationships among the PKA-, RhoA- and integrin-mediated intracellular signal transduction pathways.

\section{Materials and methods}

Cell lines and reagents. The human gastric adenocarcinoma cell line SGC-7901 was provided by the Institute of Biochemistry and Cell Biology, Shanghai Institutes for Biological Sciences, Chinese Academy of Sciences, China. Dulbecco's modified Eagle's medium (DMEM) was from Gibco (Grand Island, NY, USA). Fetal calf serum (FCS) and newborn calf serum were from Minhai Bio-engineering Co. Ltd. (Lanzhou, China). Mouse monoclonal antibody against RhoA was from Santa Cruz Biotechnology (Santa Cruz, CA, USA). Goat anti-mouse and rabbit horseradish peroxidase-conjugated secondary antibodies were from Jackson ImmunoResearch Laboratories (West Grove, PA,USA). The ${ }^{125}$ I-cAMPradioimmunoassay (RIA) kit was from the Nuclear Medical Laboratory of the Shanghai University of Traditional Chinese Medicine, China. Rabbit antibody against PKA catalytic subunit (PKA-C)- $\alpha$ and rabbit antibody against p-vasodilator-stimulated phosphoprotein (p-VASP) were from Santa Cruz Biotechnology. Fibronectin (from bovine plasma) and pertussis toxin were from Sigma (St. Louis, MO, USA). Enhanced chemiluminescence (ECL) reagents were from Amersham Biosciences (Buckinghamshire, UK).

Preparation of Rhotekin-GST. The plasmid DNA encoding RhoA binding domain of Rhotekin fused to glutathione-Stransferase (GST) was transfected into $E$. coli. The bacteria were cultured at $37^{\circ} \mathrm{C}$ overnight and then induced with isopropyl- $\beta$ D-thiogalactopyranoside at $30^{\circ} \mathrm{C}$ for $2 \mathrm{~h}$ to express proteins. The bacteria cells were lysed with lysis buffer containing $50 \mathrm{mmol} / \mathrm{l}$ Tris- $\mathrm{HCl} \mathrm{pH}$ 7.4, 1\% NP-40, $150 \mathrm{mmol} / \mathrm{l} \mathrm{NaCl}$, 
$5 \mathrm{mmol} / \mathrm{l} \mathrm{MgCl}, 1 \mathrm{mmol} / \mathrm{l}$ dithiothreitol (DTT), $10 \mu \mathrm{g} / \mathrm{ml}$ aprotinin, $10 \mu \mathrm{g} / \mathrm{ml}$ leupeptin and $1 \mathrm{mmol} / \mathrm{l}$ phenylmethansulfonyl fluoride. The lysate was centrifuged, and the supernatant was incubated with glutathione beads at $4^{\circ} \mathrm{C}$ for $2 \mathrm{~h}$. The beads were washed five times with washing buffer containing $50 \mathrm{mmol} / \mathrm{l}$ Tris-HCl pH 7.4, $0.5 \%$ Triton X-100, $150 \mathrm{mmol} / \mathrm{l} \mathrm{NaCl}$, $5 \mathrm{mmol} / 1 \mathrm{MgCl}_{2}$ and $1 \mathrm{mmol} / \mathrm{l} \mathrm{DTT}$. After the final washing, the beads were suspended in washing buffer containing $10 \%$ glycerol and maintained at $-70^{\circ} \mathrm{C}$ until use.

RhoA-GTP pull-down assay. Rho activity was measured according to the method of Ren et al (11). Briefly, $3 \times 10^{6}$ cells were seeded on a $10-\mathrm{cm}$ dish. Following various treatments, the cells were washed with Tris-buffered saline (TBS) and lysed with $400 \mu 1$ lysis buffer containing $50 \mathrm{mmol} / \mathrm{l}$ Tris- $\mathrm{HCl} \mathrm{pH} \mathrm{7.4,}$ $1 \% \mathrm{NP}-40,1 \%$ CHAPS, $200 \mathrm{mmol} / 1 \mathrm{NaCl}, 1 \mathrm{mmol} / 1 \mathrm{MgCl}_{2}$, $10 \mu \mathrm{g} / \mathrm{ml}$ leupeptin, $10 \mu \mathrm{g} / \mathrm{ml}$ aprotinin and $1 \mathrm{mM}$ PMSF. The cell lysate was centrifuged to eliminate the cell debris. As a loading control, $10 \mu \mathrm{l}$ of supernatant was reserved, and the remainder was incubated with GST-Rhotekin-glutathione beads at $4^{\circ} \mathrm{C}$ for $45 \mathrm{~min}$, with continuous agitation. The beads were washed three times with buffer containing $50 \mathrm{mmol} / \mathrm{l}$ Tris- $\mathrm{HCl} \mathrm{pH} \mathrm{7.4,} \mathrm{2 \%} \mathrm{NP-40,} 200 \mathrm{mmol} / \mathrm{l} \mathrm{NaCl}$ and $10 \mathrm{mmol} / \mathrm{l}$ $\mathrm{MgSO}_{4}$. After the final washing, $20 \mu \mathrm{l}$ of $2 \mathrm{X}$ sodium dodecyl sulfate polyacrylamide gel electrophoresis (SDS-PAGE) loading buffer was added to the beads, then the beads were boiled for $5 \mathrm{~min}$ to release the proteins.

Western blotting. SDS-PAGE gels of various concentrations were cast according to the molecular size of the target proteins. Sample proteins were accumulated using a voltage of $80 \mathrm{~V} / \mathrm{cm}$ and then separated using a voltage of $120 \mathrm{~V} / \mathrm{cm}$ on gel. Following electrophoresis, the proteins on the gel were transferred onto a polyvinylidene fluoride membrane, and the membrane was blocked with $3 \%$ bovine serum albumin (BSA) in TBS-T for $1 \mathrm{~h}$ at room temperature (RT). Incubation with the primary antibody was carried out at $4^{\circ} \mathrm{C}$ overnight, and incubation with the secondary antibody was carried out at RT for $50 \mathrm{~min}$, with washing three times after each incubation. ECL reagents were used to visualize the positive bands on the membrane. Briefly, same volumes of solution A and solution B were combined and added to the protein side of the membrane, followed by incubation at RT for $1 \mathrm{~min}$. The exposure time of the first film was $15 \mathrm{sec}$. The exposure time of the second film was adjusted according to the intensity of the signals on the first film.

Fluorescence microscopy. The cells grown on cover slips were fixed with freshly prepared $2 \%$ paraformaldehyde in phosphate-buffered saline (PBS). After being permeabilized with $0.3 \%$ Triton X-100 and washed with PBS, the cells were incubated with the primary antibody (PKA-C- $\alpha$ antibody; $1: 200)$ for $2 \mathrm{~h}$ at RT and then with a fluorescein isothiocyanateconjugated secondary antibody (1:50) for $1 \mathrm{~h}$ at RT, with three washes after each incubation. The distribution of PKA-C in the cells was observed using fluorescence microscopy.

Radioimmunoassay of cAMP. SGC-7901 cells were placed in 12-well plates at a density of $10^{5}$ cells/well with DMEM supplemented with $10 \%$ FCS. Following various treatments, the cells were rapidly collected and re-suspended in $50 \mathrm{mM}$ acetate buffer at $\mathrm{pH} 4.75$. The samples were frozen and thawed
A

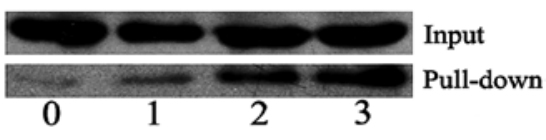

B

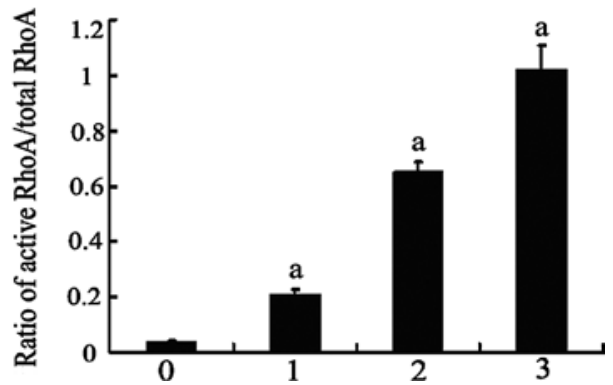

Figure 1. Rho activity in SGC-7901 cells treated with soluble fibronectin. Cell lysate input (2.5\% of total lysate) and pull-down of GTP-RhoA were analyzed by Western blotting with an antibody against RhoA. (A) Western blotting: lane 0 , untreated cells; lane 1 , cells treated with $10 \mu \mathrm{g} / \mathrm{ml}$ fibronectin for $5 \mathrm{~min}$; lane 2, cells treated with $10 \mu \mathrm{g} / \mathrm{ml}$ fibronectin for $15 \mathrm{~min}$; lane 3 , cells treated with $10 \mu \mathrm{g} / \mathrm{ml}$ fibronectin for $30 \mathrm{~min}$. (B) Western blotting results were analyzed by GeneSnap/GeneTools software, and the raw volume ratio of active RhoA to RhoA input (pull-down/input) was calculated and presented. Each bar represents the mean \pm SD obtained from three independent experiments. ${ }^{a} \mathrm{P}<0.01$ compared to bar 0 .

three times, followed by sonication seven to eight times. The levels of cAMP were determined by competition binding with [25I]-succinyladenosine 3',5'-cyclic monophosphate tyrosyl methyl ester (ScAMP-TME). The amount of bound radioactivity was determined by $\gamma$ counting. The cAMP level of each sample was measured using commercial RIA kits as previously described (12).

Reporter gene assay. Cells were seeded on a 24-well plate the day before transfection. pCRE-Luc and $\beta$-gal plasmid DNA (0.8 $\mu \mathrm{g} /$ well) was transfected using Lipofectamine 2000 according to the manufacturer's instructions (Invitrogen, Carlsbad, CA, USA). After incubation at $37^{\circ} \mathrm{C}$ in $5 \% \mathrm{CO}_{2}$ for 18-20 h, the cells were treated with cAMP or forskolin for $7.5 \mathrm{~h}$. Certain cells were pre-treated with fibronectin for $30 \mathrm{~min}$. The cells were lysed, and the lysate was used for luciferase and $\beta$-galactosidase activity assay. Luminescence was measured in a luminometer.

Statistical analysis. Data are expressed as the means \pm standard deviation (SD). Statistical significance was tested with the Student's t-test, and $\mathrm{P}<0.05$ was considered a significant difference.

\section{Results}

Soluble fibronectin increases RhoA activity in SGC-7901 cells. Typically, fibronectin is used to coat the culture surface so that integrin on the cells is activated when the cells attach to the surface. In this experiment, fibronectin was added to the culture medium to ascertain whether or not soluble fibronectin activates integrin. Addition of fibronectin to the culture medium of the SGC-7901 cells time-dependently increased RhoA activity (Fig. 1). This indicated that soluble fibronectin had the same biological activity as attached fibronectin. In the subsequent experiments, soluble fibronectin was applied to examine the effect of this protein. 
A

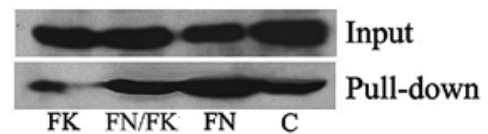

B

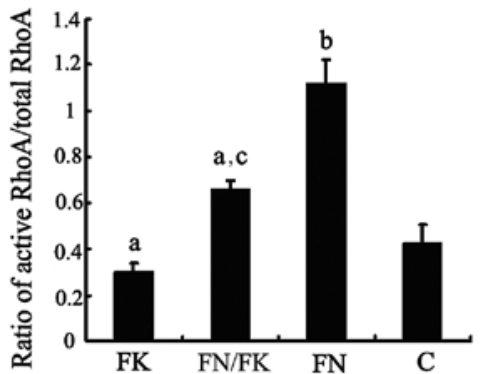

Figure 2. Rho activity in SGC-7901 cells treated with soluble fibronectin followed by forskolin. Cell lysate input ( $2.5 \%$ of total lysate) and pull-down of GTP-RhoA were analyzed by Western blotting with an antibody against RhoA. (A) Western blotting: lane FK, cells treated with $10 \mu \mathrm{M}$ forskolin for $25 \mathrm{~min}$; lane FN/FK, cells treated with $10 \mu \mathrm{g} / \mathrm{ml}$ fibronectin for $5 \mathrm{~min}$ followed by $10 \mu \mathrm{M}$ forskolin for $25 \mathrm{~min}$; lane $\mathrm{FN}$, cells treated with $10 \mu \mathrm{g}$ / $\mathrm{ml}$ fibronectin for $30 \mathrm{~min}$; lane $\mathrm{C}$, untreated cells. (B) The Western blotting results were analyzed by GeneSnap/GeneTools software, and the raw volume ratio of active RhoA to RhoA input (pull-down/input) was calculated and presented. Each bar represents the mean $\pm \mathrm{SD}$ obtained from three independent experiments. ${ }^{a} \mathrm{P}<0.05$ compared to bar $\mathrm{C}$; ${ }^{\mathrm{b}} \mathrm{P}<0.01$ compared to bar $\mathrm{C}$; ${ }^{\mathrm{c}} \mathrm{P}<0.01$ compared to bar FK

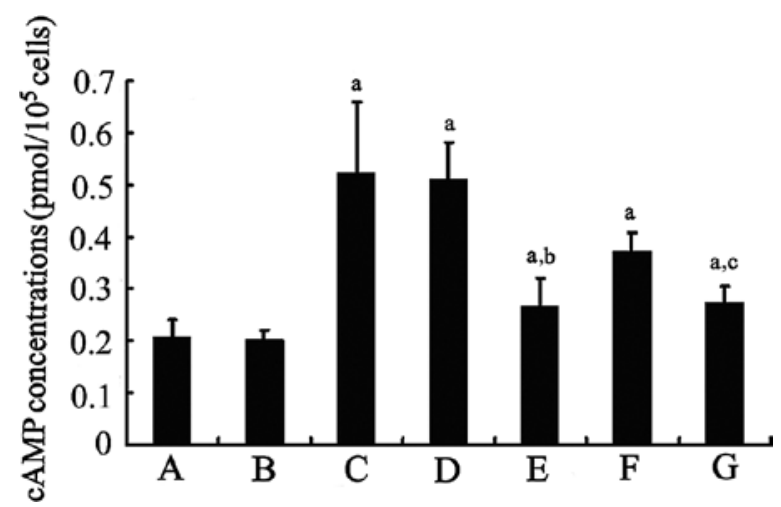

Figure 3. Concentration of cAMP in SGC-7901 cells with various treatments The levels of cAMP were determined by competition binding with [ $\left.{ }^{125} \mathrm{I}\right]-$ succinyladenosine 3',5'-cyclic monophosphate tyrosyl methyl ester (ScAMPTME). A, Untreated cells; B, cells treated with $10 \mu \mathrm{g} / \mathrm{ml}$ fibronectin for $2 \mathrm{~h}$; $\mathrm{C}$, cells treated with $10 \mu \mathrm{M}$ forskolin for $1.5 \mathrm{~h}$; D, cells treated with $1.0 \mu \mathrm{g} /$ $\mathrm{ml}$ fibronectin for $30 \mathrm{~min}$ followed by $10 \mu \mathrm{M}$ forskolin for $1.5 \mathrm{~h}$; E, cells treated with $10 \mu \mathrm{g} / \mathrm{ml}$ fibronectin for $30 \mathrm{~min}$ followed by $10 \mu \mathrm{M}$ forskolin for $1.5 \mathrm{~h} ; \mathrm{F}$, cells treated with $400 \mathrm{ng} / \mathrm{ml}$ pertussis toxin for $12 \mathrm{~h} ; \mathrm{G}$, cells treated with $10 \mu \mathrm{g} / \mathrm{ml}$ forskolin for $30 \mathrm{~min}$ followed by $400 \mathrm{ng} / \mathrm{ml}$ pertussis toxin for $12 \mathrm{~h}$. The results represent the mean \pm SD of three independent experiments. ${ }^{a} \mathrm{P}<0.01$ compared to bar $\mathrm{A}$; ${ }^{\mathrm{b}} \mathrm{P}<0.001$ compared to bar $\mathrm{C}$; ${ }^{\mathrm{c}} \mathrm{P}<0.01$ compared to bar F.
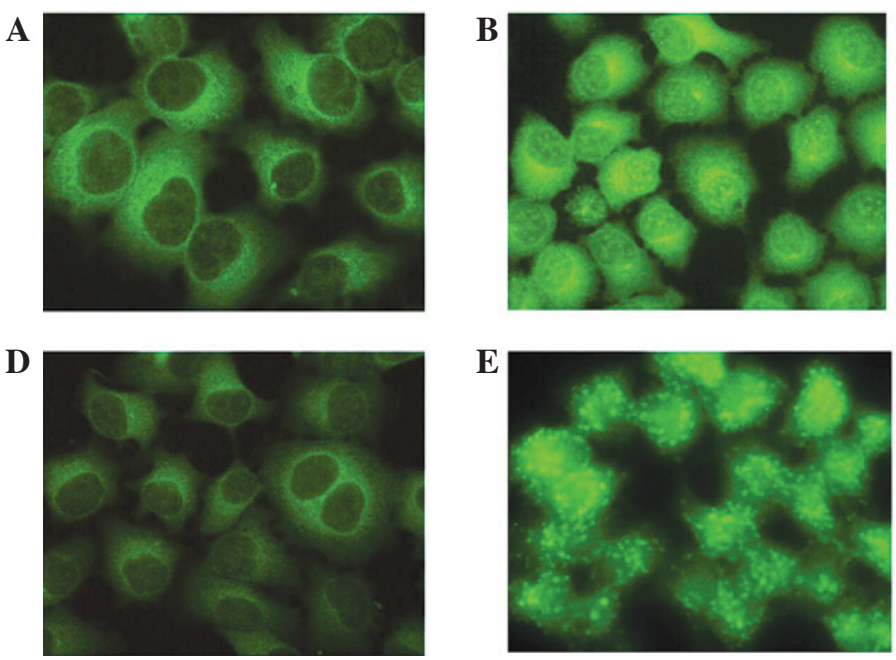
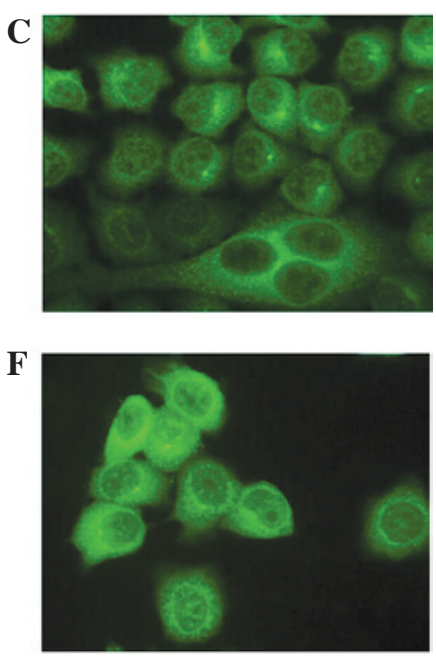

Figure 4. Effects of soluble fibronectin on PKA-C distribution in SGC-7901 cells, shown by immunofluorescence microscopy. (A) Untreated cells; (B) cells treated with $10 \mu \mathrm{M}$ forskolin for $1.5 \mathrm{~h}$; (C) cells treated with $10 \mu \mathrm{g} / \mathrm{ml}$ fibronectin for 30 min followed by $10 \mu \mathrm{M}$ forskolin for $1.5 \mathrm{~h}$; (D) cells treated with $10 \mu \mathrm{g} / \mathrm{ml}$ fibronectin for $2 \mathrm{~h}$; (E) cells treated with $800 \mathrm{ng} / \mathrm{ml}$ pertussis toxin for $18 \mathrm{~h}$; (F) cells treated with $10 \mu \mathrm{g} / \mathrm{ml}$ fibronectin for $30 \mathrm{~min}$ followed by $800 \mathrm{ng} / \mathrm{ml}$ pertussis toxin for $18 \mathrm{~h}$. Original magnification, $\mathrm{x} 400$ for fluorescence microscopic images.

Fibronectin blocks the inhibition of $c A M P / P K A$ on RhoA activity. To explore the relationships among integrin, PKA and RhoA, the cells were treated with forskolin, an activator of adenylate cyclase, to increase the concentration of cAMP and the activity of PKA. This treatment caused a significant decrease in RhoA activity. The cells were then treated with fibronectin followed by forskolin treatment. Treatment of the cells with $10 \mu \mathrm{g} / \mathrm{ml}$ fibronectin prevented forskolin-induced inhibition of RhoA activity (Fig. 2).

Fibronectin decreases the intracellular cAMP concentration in SGC-7901 cells. In the cultured SGC-7901 cells, fibronectin treatment had little effect on the basal level of
cAMP. The cAMP level was significantly increased by forskolin and pertussis toxin. However, in cells treated with fibronectin followed by forskolin and pertussis toxin treatment, the increase in the cAMP level induced by forskolin and pertussis toxin was blocked by fibronectin treatment (Fig. 3). Since forskolin is an activator of adenylate cyclase and pertussis toxin is an inhibitor of inhibitory $G$ protein, these results suggest that fibronectin decreases the cAMP level by inhibiting the activity of adenylate cyclase.

Fibronectin prevents the nuclear location of the PKA catalytic subunit in SGC-7901 cells. To examine the changes in the distribution of the PKA-C induced by fibronectin, 
$\mathbf{A}$

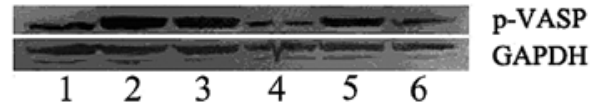

B

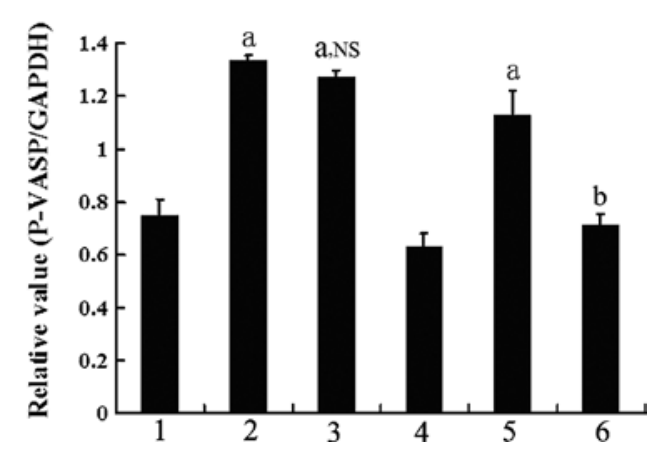

Figure 5. Effects of soluble fibronectin, cAMP and forskolin on the phosphorylation of VASP in SGC-7901 cells. (A) Using Western blotting, the expression of p-VASP and GAPDH in each fraction was detected. Lane 1, untreated cells; lane 2, cells treated with $100 \mu \mathrm{M}$ cAMP for $30 \mathrm{~min}$; lane 3, cells treated with $10 \mu \mathrm{g} / \mathrm{ml}$ fibronectin for $4.5 \mathrm{~h}$ followed by $100 \mu \mathrm{M}$ cAMP for $30 \mathrm{~min}$; lane 4 , cells treated with $10 \mu \mathrm{g} / \mathrm{ml}$ fibronectin for $5 \mathrm{~h}$; lane 5 , cells treated with $10 \mu \mathrm{M}$ forskolin for $30 \mathrm{~min}$; lane 6, cells treated with $10 \mu \mathrm{g} /$ $\mathrm{ml}$ fibronectin for $4.5 \mathrm{~h}$ followed by forskolin for $30 \mathrm{~min}$. (B) Western blotting results were analyzed by GeneSnap/GeneTools software, and the raw volume ratio of $\mathrm{p}$-VASP/GAPDH input was calculated and presented. Each bar represents mean \pm SD obtained from three independent experiments. aP $<0.001$ compared to bar $1 ;{ }^{\mathrm{b}} \mathrm{P}<0.01$ compared to bar 5 ; NS, not significant as compared to bar 2 .

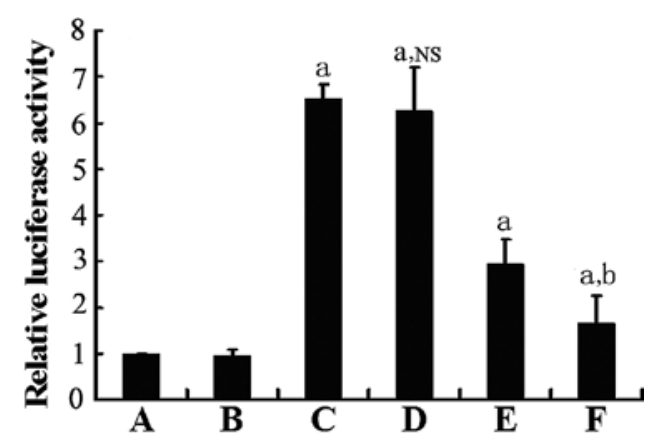

Figure 6. Effects of soluble fibronectin on cAMP response element-dependent transcription in SGC-7901 cells. The cells were transfected with pCRE-luc and $\mathrm{p} \beta \mathrm{Gal}$. Firefly luciferase activities were normalized to activities in each sample, and the relative luciferase activity measured in the untreated cells (A) was assigned the value of 1 . A, Untreated cells; B, cells treated with $10 \mu \mathrm{g} / \mathrm{ml}$ fibronectin for $8 \mathrm{~h}$; C, cells treated with $100 \mu \mathrm{M}$ cAMP for $7.5 \mathrm{~h}$; $\mathrm{D}$, cells treated with $10 \mu \mathrm{g} / \mathrm{ml}$ fibronectin for 30 min followed by $100 \mu \mathrm{M}$ cAMP for $7.5 \mathrm{~h}$; E, cells treated with $10 \mu \mathrm{M}$ forskolin for $7.5 \mathrm{~h}$; F, cells treated with $10 \mu \mathrm{g} / \mathrm{ml}$ fibronectin for $30 \mathrm{~min}$ followed by $10 \mu \mathrm{M}$ forskolin for $7.5 \mathrm{~h}$. Values are mean $\pm \mathrm{SD}$ obtained from three independent experiments. ${ }^{\mathrm{a}} \mathrm{P}<0.01$ compared to bar $\mathrm{A}$; ${ }^{\mathrm{b}} \mathrm{P}<0.01$ compared to bar $\mathrm{E}$; NS, not significant as compared to bar $\mathrm{C}$.

immunofluorescence microscopy with an antibody against PKA-C was applied to detect the location of PKA-C. The results revealed that forskolin and pertussis toxin, not only increased the fluorescent signal of PKA-C, but also increased the nuclear distribution of the subunit; however, these increases were blocked by fibronectin (Fig. 4).

Fibronectin decreases the p-VASP level in SGC-7901 cells. To examine the changes in PKA activity induced by fibronectin, the phosphorylation of VASP in cultured SGC-7901 cells was detected by Western blotting. The p-VASP level was significantly increased by both cAMP and forskolin. However, only the phosphorylation of VASP induced by forskolin was prevented by fibronectin treatment (Fig. 5).

Effects of fibronectin on cAMP response element-dependent transcription. To further confirm the inhibition of fibronectin on cAMP/PKA-mediated signal transduction, cAMP response element (CRE)-dependent transcription was analyzed by reporter gene assay. The results revealed that forskolin stimulation caused an $\sim 2.95$-fold increase in CRE-dependent transcription in the SGC-7901 cells. Treatment of cells with $10 \mu \mathrm{g} / \mathrm{ml}$ fibronectin for $30 \mathrm{~min}$ prior to the treatment with $10 \mu \mathrm{M}$ forskolin for $7.5 \mathrm{~h}$ significantly decreased the transcription activity induced by forskolin, while treatment of the cells with CPT-cAMP caused a 6.51-fold increase in CRE-dependent transcription; pre-treatment with fibronectin did not suppress this increase (Fig. 6).

\section{Discussion}

Integrin consists of one $\alpha$ - and one $\beta$-subunit. To date, $8 \beta$-subunits and $18 \alpha$-subunits have been identified, and these subunits may assemble into 24 distinct integrins (13). Among them, integrin $\alpha 5 \beta 1$ is a fibronectin receptor. When cells attach to extracellular matrix containing fibronectin, integrin $\alpha 5 \beta 1$ is activated (14). The activated integrin then associates with G protein and causes a switch of the protein from GDP- to GTP-binding (15). The GTP-binding G protein triggers signal transduction and causes an alteration in cellular activity.

There have been numerous studies on fibronectin/ integrin-mediated signal transduction, and the majority have investigated the interaction between fibronectin and integrin through the attachment of cells to the extracellular matrix containing fibronectin $(16,17)$. However, a large portion of fibronectin is soluble within the body. Soluble fibronectin exists mainly in the blood plasma and reaches each part of the body through the blood stream. There is no research data addressing whether soluble fibronectin activates integrinmediated signal transduction. Our results revealed for the first time that adding soluble fibronectin to culture medium caused the activation of RhoA, a crucial event in integrin-mediated signal transduction. This indicates that soluble fibronectin also binds integrin and activates consequent signaling events.

The active RhoA pull-down assay revealed that forskolin, an adenylate cyclase activator, induced the inhibition of RhoA activity. Treatment with fibronectin prevented this inhibition. These results suggest that fibronectin/integrin-mediated signaling increases RhoA activity through the inhibition of PKA activity. Therefore, elucidating the relationships among fibronectin, PKA and RhoA will provide evidence for the mechanism by which fibronectin activates RhoA.

Our previous investigation revealed that cAMP/PKA signaling inhibited RhoA activation through phosphorylation of RhoA on serine188 and antagonized RhoA functions in regulating stress fiber formation, changes in morphology, motility and the anchorage-independent growth of cancer cells (7). In order to explore the relationship between the fibronectin/integrin-mediated and cAMP/PKA-mediated signaling pathways, we examined the effect of fibronectin on 
intracellular cAMP concentration in cultured SGC-7901 cells. Our results revealed that fibronectin decreased the cAMP level in association with adenylate cyclase. We examined the effect of fibronectin on PKA activity. PKA is an isozyme existing as a tetramer of two R- and two C-subunits. The isozyme is activated by the binding of cAMP to the A and B binding sites located in the carboxyl two-thirds of the R-subunits (18). Occupancy of the R-subunits by cAMP subsequently results in the rapid dissociation of the holoenzyme, allowing the catalytically active C-subunit to phosphorylate substrates $(19,20)$. To examine the activation of PKA, we detected the distribution of PKA-C. Immunofluorescent staining indicated that nuclear PKA-C was significantly increased by forskolin and pertussis toxin and these increases were blocked by fibronectin.

We then detected the phosphorylation of VASP to indicate the activity of PKA. VASP was first identified as a substrate of PKA and PKG, which are regulated by cyclic nucleotides $(21,22)$. This protein has three PKA/PKG phosphorylation sites, Ser157, Ser239 and Thr278; Ser157 is the preferred target for PKA, while Ser239 is preferentially phosphorylated by PKG (23). As a major substrate for PKA, VASP proteins are used to assess the activation of the PKA signaling pathway. Our results revealed that both cAMP and forskolin increased the level of p-VASP Ser157. However, only the phosphorylation of VASP caused by treatment with forskolin was prevented by fibronectin, while fibronectin had no effect on the phosphorylation of VASP caused by treatment with cAMP. These results not only reveal that fibronectin inhibits the activation of PKA, but also suggests that adenylated cyclase was the point of action of fibronectin/integrin. Once cAMP was formed, fibronectin was incapable of blocking its effect.

CREB is a 43-kDa transcription factor found exclusively in the nucleus. CREB typically binds to the CRE as a homodimer, but is transcriptionally inactive until phosphorylated at Ser133 by PKA $(24,25)$. In order to observe the effects of soluble fibronectin on CRE-dependent transcription, we measured CRE-directed reporter gene expression. The results revealed that treating cells with $10 \mu \mathrm{M}$ forskolin for $7.5 \mathrm{~h}$ induced a 2.9-fold increase in transcription activity. Pre-treatment with $10 \mu \mathrm{g} / \mathrm{ml}$ fibronectin for 30 min significantly decreased transcription activity, while treating the cells with CPT-cAMP induced a 6.5-fold increase in CRE-dependent transcription; fibronectin treatment did not suppress this increase. These results revealed that fibronectin inhibits CRE-directed reporter gene expression by suppressing the activity of adenylate cyclase.

In conclusion, our results provide evidence that fibronectin/ integrin induces RhoA activation through the inhibition of cAMP/PKA-mediated signal transduction. The possible point of action of fibronectin/integrin is adenylate cyclase. This not only aids in the understanding of the relationships among the fibronectin/integrin-, cAMP/PKA- and RhoA-mediated signal transduction pathways, but also provides a novel target for cancer therapy.

\section{Acknowledgements}

This study was supported by the National Natural Science Foundation of China, no. 30470891, and by the Innovation Grant of Jiangsu University.

\section{References}

1. Hynes RO: Integrins versatility modulation and signaling in cell adhesion. Cell 69: 11-25, 1992.

2. Slack-Davis JK and Parsons JT: Emerging views of integrin signaling: implications for prostate cancer. J Cell Biochem 91: 41-46, 2004.

3. Kjoller L and Hall A: Signaling to Rho GTPases. Exp Cell Res 253: 166-179, 1999.

4. Takai Y, Sasaki T and Matozaki T: Small GTP-binding proteins: Review. Physiol Rev 81: 153-208, 2001.

5. Sahai E and Marshall CJ: RHO-GTPases and cancer. Nat Rev Cancer 2: 133-142, 2002.

6. Narumiya S: The small GTPase Rho: cellular functions and signal transduction. J Biochem 120: 215-228, 1996.

7. Chen YC, Wang Y, Yu H, Wang FW and Xu WR: The cross talk between protein kinase A- and RhoA-mediated signaling in cancer cells. Exp Biol Med 230: 731-741, 2005.

8. Tao Y, Chen YC, Li YY, Yang SQ and Xu WR: Localization and translocation of RhoA protein in the human gastric cancer cell line SGC-7901. World J Gastroenterol 14: 1175-1181, 2008.

9. Vial E, Sahai E and Marshall CJ: ERK-MAPK signaling coordinately regulates activity of Rac1 and RhoA for tumor cell motility. Cancer Cell 4: 67-79, 2003.

10. Wang Y, Chen Y, Chen M and Xu W: AKAPs competing peptide HT31 disrupts the inhibitory effect of PKA on RhoA activity. Oncol Rep 16: 755-761, 2006.

11. Ren X-D, Kiosses WB and Schwartz MA: Regulation of the small GTP-binding protein Rho by cell adhesion and the cytoskeleton. EMBO J 18: 578-585, 1999.

12. Wang Z, Shi F, Jiang YQ, Lu LZ, Wang H, Watanabe G and Taya K: Changes of cyclic AMP levels and phosphodiesterase activities in the rat ovary. J Reprod Dev 53: 717-725, 2007.

13. Humphries MJ: Integrin structure. Biochem Soc Trans 28: 311-340, 2000.

14. Pytela R, Pierschbacher MD and Ruoslahti E: Identification and isolation of a $140 \mathrm{kd}$ cell surface glycoprotein with properties expected of a fibronectin receptor. Cell 40: 191-198, 1985.

15. Gong H, Shen B, Flevaris P, Chow C, Lam SC, VoynoYasenetskaya TA, Kozasa T and Du X: G protein subunit Galpha13 binds to integrin alphaIIbbeta3 and mediates integrin 'outside-in' signaling. Science 327: 340-343, 2010.

16. Milliano MT and Luxon BA: Initial signaling of the fibronectin receptor (alpha5beta1 integrin) in hepatic stellate cells is independent of tyrosine phosphorylation. J Hepatol 39: 32-37, 2003.

17. Lee M, Park JJ and Lee YS: Adhesion of ST6Gal I-mediated human colon cancer cells to fibronectin contributes to cell survival by integrin betal-mediated paxillin and AKT activation. Oncol Rep 23: 757-761, 2010.

18. Taylor SS, Radzio-Andzelm E, Madhusudan, Cheng X, Ten Eyck L and Narayana N: Catalytic subunit of cyclic AMP-dependent protein kinase: structure and dynamics of the active site cleft. Pharmacol Ther 82: 133-141, 1999.

19. Skalhegg BS and Tasken K: Specificity in the cAMP/PKA signaling pathway: differential expression, regulation, and subcellular localization of subunits of PKA. Front Biosci 5: D678-D-693, 2000.

20. Francis SH and Corbin JD: Cyclic nucleotide-dependent protein kinases: intracellular receptors for cAMP and cGMP action. Crit Rev Clin Lab Sci 36: 275-328, 1999.

21. Reinhard M, Halbrügge M, Scheer U, Wiegand C, Jockusch BM and Walter U: The $46 / 50 \mathrm{kDa}$ phosphoprotein VASP purified from human platelets is a novel protein associated with actin filaments and focal contacts. EMBO J 11: 2063-2070, 1992.

22. Lee S and Chung CY: Role of VASP phosphorylation for the regulation of microglia chemotaxis via the regulation of focal adhesion formation/maturation. Mol Cell Neurosci 42: 382-390, 2009.

23. Krause M, Dent EW, Bear JE, Loureiro JJ and Gertler FB: Ena/ VASP proteins: regulators of the actin cytoskeleton and cell migration. Annu Rev Cell Dev Biol 19: 541-564, 2003.

24. Shaywitz AJ and Greenberg ME: CREB: a stimulus-induced transcription factor activated by a diverse array of extracellular signals. Annu Rev Biochem 68: 821-861, 1999.

25. Elliott MR, Tolnay M, Tsokos GC and Kammer GM: Protein kinase A regulatory subunit type II beta directly interacts with and suppresses CREB transcriptional activity in activated T cells. J Immunol 171: 3636-3644, 2003. 